Sains Malaysiana 50(10)(2021): 2913-2921

http://doi.org/10.17576/jsm-2021-5010-06

\title{
Response of Primed Rice (Oryza sativa L.) Seeds towards Reproductive Stage Drought Stress
}

(Tindak Balas Benih Biji Benih Padi (Oryza sativa L.) Terawat terhadap Tekanan Kemarau di Peringkat Pembiakan)

\author{
Mohd Syahmi Salleh, Mohd Shukor Nordin, Adam B. Puteh, Rozilawati Shahari, Zarina Zainuddin, \\ MOHAMAd BAHAgIA AB-GHAFFaR \& NORAZIYAH ABD AZIZ SHAMSUdin*
}

\begin{abstract}
Seed priming could be promoted as a potential alternative in alleviating drought stress challenges in rice cultivation. The present study was conducted as an attempt to verify potential performance of seed priming in improving seedling growth and harvestable grain yield of rice under reproductive stage drought stress (RS). Seed treatments involved were non-primed seeds as control (T1), hydro-primed (T2) and osmo-primed at -1.0 mPa with polyethylene glycol (PEG6000) (T3). Reproductive stage drought stress (RS) was imposed at soil water potential lower than -60 kPa. The well-watered plants served as control of the experiment. In general, seedling growth of T3 was better than T2 and T1 for all growth parameters in both planting seasons. Yield components were significantly lower in RS as compared to well-watered treatment $(W W)$. The agronomic performance of primed seeds in T2 and T3 were not significantly different with T1 under both RS and WW for both planting seasons. As a conclusion, seed priming treatments used in this study was ineffective in improving agronomic performance of rice under RS. Therefore, other alternatives such as development of drought tolerant rice should be highly emphasized in order to minimize the impact of drought on growth and yield of rice plant.
\end{abstract}

Keywords: Growth; hydro-primed; polyethylene glycol; yield components

\section{ABSTRAK}

Rawatan biji benih berpotensi untuk dipromosikan sebagai alternatif bagi mengatasi masalah tekanan kemarau pada fasa pembiakan bagi penanaman padi. Kajian ini dijalankan bagi membuktikan potensi rawatan biji benih bagi meningkatkan pertumbuhan anak benih dan hasil padi dalam keadaan tekanan kemarau pada fasa pembiakan (RS). Rawatan biji benih yang terlibat ialah biji benih yang tidak dirawat sebagai kawalan uji kaji (T1), hidro prima (T2) dan osmo prima pada -1.0 mPa menggunakan polietilena glikol (PEG6000) (T3). Tekanan kemarau pada fasa pembiakan (RS) dikenakan pada kadar keupayaan air dalam tanah di tahap -60 kPa. Pokok yang diberi air secukupnya berfungsi sebagai kawalan. Secara umumnya, pertumbuhan anak pokok T3 adalah lebih baik berbanding T2 dan T1 bagi kesemua parameter pertumbuhan dan musim penanaman. Komponen hasil didapati lebih rendah secara signifikan dalam RS berbanding WW. Prestasi agronomi rawatan biji benih T2 dan T3 adalah tidak berbeza secara signifikan dengan T1 bagi kedua-dua keadaan RS dan WW untuk kedua-dua musim penanaman. Kesimpulannya, rawatan biji benih yang digunakan dalam kajian ini adalah tidak berkesan untuk meningkatkan prestasi agronomi padi di bawah RS. Oleh yang demikian, alternatif lain iaitu penghasilan padi yang toleran terhadap RS perlulah diberikan perhatian bagi mengurangkan impak kemarau terhadap pertumbuhan dan hasil pokok.

Kata kunci: Hidro prima; komponen hasil; pertumbuhan; polietilena glikol

\section{INTRODUCTION}

Rice (Oryza sativa L.) is among the most important crop in the world. Occurrence of El-Nino and prolonged drought season has jeopardize global rice production and food security (Shamsudin et al. 2016a). The most vulnerable stage to drought is during reproductive stage
(Ikmal et al. 2019, 2018; Swamy et al. 2017), ranging from booting to heading (Salleh et al. 2018). Moreover, Salleh et al. (2020) suggested that seed priming could be promoted as a potential alternative in alleviating drought stress challenges in rice cultivation. The strategy could be described as a pre-sowing treatment by; 1) partial 
hydration and imbibition called hydropriming; or 2) restricted imbibition by soaking the seeds into osmotic solution called osmopriming (Chen \& Arora 2013). Hydropriming or also known as on-farm seed priming is widely used by rice farmers in India, Nepal and Pakistan (Harris et al. 2001). High farmer's acceptance for this strategy could be due to the simplicity, low cost and easy to operate in nature. Harris et al. (1999) reported that farmer's acceptance rate towards on-farm seed priming strategy is extremely high, between $95-100 \%$. This could be due to direct benefits of on-farm seed priming mainly faster emergence, better crop stands, lower incidence of re-sowing, more vigorous plants and higher grain yield (GY). However, the effectiveness of this priming technique in improving germination and seedling growth performance under reproductive drought stress (RS) might be lower compared to osmopriming strategy (Chen \& Arora 2013).

Lutts et al. (2016) reported that soaking the seeds in polyethylene glycol (PEG) solution (osmopriming strategy) significantly improved seed germination, seedling emergence, and stress tolerance of various crops under unfavourable conditions. Mouradi et al. (2016) reported that osmopriming with PEG6000 enhanced germination potential and increased speed of seed germination under RS condition. Jisha et al. (2013) stated that osmopriming using PEG solution allows initiation of membrane repairing systems and metabolic preparation for germination due to restricted imbibition process. The $\alpha$-amylase activity was also higher in osmo-primed seeds resulted in accelerated starch hydrolysis, the rapid growth of the embryo and synchronize germination performance (Basra et al. 2005; Lee \& Kim 1999).

In addition, seed priming induces faster emergence, uniform crop stand, higher growth rates and dry matter increment, early flowering, increase seed tolerance to the adverse environment and higher yield in various crops such as wheat, rice, maize and soybean (Harris et al. 2001; Salehzade et al. 2009). Higher yield recorded in the primed seeds of various crops may be associated with higher field emergence, greater growth traits such as the leaf area index (LAI), crop growth rate (CGR) and leaf area duration, higher number of fertile tillers and better maintenance of photosynthetic activity associated with high chlorophyll contents during reproductive stage (Farooq et al. 2019).

Mahajan et al. (2011) reported that seed priming significantly improves seedling growth, LAI, number of panicles and GY of dry direct-seeded rice. Musa et al. (1999) also reported positive effects of seed priming such as significantly faster seedlings emergence, better stand establishment and about $47 \%$ increment in harvestable GY. A similar outcome was also reported by Binang et al. (2012), Farooq et al. (2006), and Harris et al. (2007). However, all those previous reports on the agronomic performance of primed seeds were under normal or wellwatered condition (WW). Information on the agronomic performance of primed seeds under RS in rice, however, is scarcely available.

In contrast, Subedi and Ma (2005) reported that although seed priming significantly improves seedling vigor and stand establishment during seedling stage, the harvestable GY of primed seeds was statistically similar with the non-primed control under both condition of glasshouse and field trial experiments. The present study hence was conducted as an attempt to verify potential performance of seed priming in improving seedling growth and harvestable GY under RS in rice.

\section{MATERIALS AND MethodS}

\section{EXPERIMENTAL DESIGN AND DROUGHT STRESS TREATMENT}

The experiment was conducted under glasshouse condition at the Glasshouse and Nursery Complex, Kulliyyah of Science, International Islamic University Malaysia (IIUM), Kuantan Campus, Pahang, Malaysia from February 2017 to May 2017 and was repeated on February 2018 to May 2018 using two-factorial randomized complete block design (RCBD) with three replications. Seeds of the two rice varieties, IR64 and MR297 were obtained from the National Rice Gene Bank, Malaysian Agricultural Research and Development Institute (MARDI), Seberang Perai, Pulau Pinang. The first factor was seed priming treatment mainly non-primed seeds as control (T1), hydro-primed (T2), and osmo-primed at $-1.0 \mathrm{mPa}$ with PEG6000 (T3) following previous study by Salleh et al. (2020). The second factor was water treatment particularly WW condition at $0 \mathrm{kPa}$ as control and RS condition at soil water potential lower than $-60 \mathrm{kPa}$.

Planting procedures, agronomic practices and procedures for reproductive stage drought was based on previous study by Salleh et al. (2018). Reproductive stage drought stress (RS) was imposed by withholding water application. The soil water potential $\left(y_{\text {soil }}\right)$ was monitored using soil tensiometer (Steizner, GmbH). Water application was resumed when soil water potential reached the desired level of RS at $-60 \mathrm{kPa}$. Control of the experiment $(\mathrm{WW})$ was left under a normal level of soil water potential $\left(y_{\text {soil }}=0 \mathrm{kPa}\right)$ throughout the study 
period. The leaf relative water content (LRWC) was also monitored during RS treatment and at the early stages of re-watering. The leaf blade was cut and the fresh weight was immediately recorded. Next, the leaf blade was soaked in distilled water for $4 \mathrm{~h}$ at $20^{\circ} \mathrm{C}$ and then blotted dry for turgid weight measurement. The dry weight was obtained after oven-dried for $48 \mathrm{~h}$ at $70{ }^{\circ} \mathrm{C}$. The LRWC was then calculated based on the equation by Schonfeld et al. (1988):

$$
L R W C=\frac{\text { fresh weight }- \text { dry weight }}{\text { turgid weight }- \text { dry weight }} \times 100
$$

\section{DATA COLLECTION}

The seedling growth attributes such as shoot length (SL), root length (RL), total seedling length (TL), LAI, leaf area duration (LAD), net assimilation rate (NAR), and CGR and the agronomic performance attributes such as number of seeds (SN), GY and harvest index (HI) were recorded. The SL, RL, and TL were recorded on the 7 and 21 days after sowing (DAS). The CGR was calculated as proposed by Hunt (1990) in $\mathrm{g}^{-1}$ day $^{-1}$, where $\mathrm{W}_{1}$ and $\mathrm{W}_{2}$ as the total dry weight $(\mathrm{g})$ harvested at time $\mathrm{t}_{1}(7 \mathrm{DAS})$ and $\mathrm{t}_{2}$ (21 DAS). Dry weight was calculated after oven drying at $70{ }^{\circ} \mathrm{C}$ until constant weight:

$$
\text { Crop growth rate }(C G R)\left(g^{-1} d a y^{-1}\right)=\frac{\left(\mathrm{W}_{2}-\mathrm{W}_{1}\right)}{\left(\mathrm{t}_{2}-\mathrm{t}_{l}\right)}
$$

The leaf area was determined through length-width method using the following formula by Watson (1947) where $\mathrm{K}$ is an adjustment factor of 0.75 ;

$$
\text { Leaf area }\left(\mathrm{cm}^{2}\right)=\text { length }(\mathrm{cm}) x \text { width }(\mathrm{cm}) \times K
$$

The LAI was calculated based on formula by Watson (1947);

$$
\begin{aligned}
& \text { Leaf area index }(L A I) \\
& =\text { total leaf area of middle tiller }\left(\mathrm{cm}^{2}\right) x \text { total number of tillers }
\end{aligned}
$$

Then, the LAD was estimated according to Hunt (1990);

$$
\text { Leaf area duration }(L A D)=\frac{L A I_{1}+L A I_{2}}{t_{2}-t_{1}} \times 2
$$

where $\mathrm{LAI}_{1}$ and $\mathrm{LAI}_{2}$ were the leaf area indices at times $\mathrm{t}_{1}$ (7 DAS) and $t_{2}$ (21 DAS).

The NAR was estimated in following Hunt (1990) where $\mathrm{W} 1$ and $\mathrm{W} 2$ were the total dry weight measured at two intervals (7 DAS and 21 DAS) during the growing season, and LAD was the leaf area duration within this interval.

Net assimilation rate $(N A R)\left(\mathrm{g} \mathrm{cm}^{-2} \mathrm{day}^{-1}\right)=\frac{W_{2}-W_{1}}{L A D}$

All seeds were harvested at harvest maturity with intact panicle and dried in an oven at $35 \pm 1^{\circ} \mathrm{C}$ until seed moisture content reached about $14 \pm 1 \%$. Seed moisture content was determined following the oven-drying method by ISTA (2016). Yield components such as SN, GY and HI were recorded per pot basis. The HI was computed based on the following formula:

$$
\text { Harvest index }(H I)=\frac{\text { Grain weight }}{\text { Total aboveground biomass }}
$$

\section{STATISTICAL ANALYSIS}

All data were analysed using Analysis of Variance (ANOVA) at $\mathrm{p} \leq 0.05$ for treatment effect followed by Duncan new multiple range test (DNMRT) for mean comparison analysis. Pearson's correlation analysis was also conducted to identify the possible association of the recorded parameters. All data were statistically analysed using the Statistical Analysis System (SAS) version 9.1.

\section{RESULTS}

\section{ENVIRONMENTAL CONDITION THROUGHOUT EXPERIMENT}

The average temperature throughout first planting season in the year 2017 was recorded at $30.51{ }^{\circ} \mathrm{C}$ with a range of minimum-maximum temperature of between $24.92{ }^{\circ} \mathrm{C}$ and $36.10{ }^{\circ} \mathrm{C}$ (Figure 1). The average value of relative humidity in 2017 was $74.26 \%$ ranging from $59.60 \%$ (minimum) to $88.92 \%$ (maximum). Almost similar value in the average temperature $\left(30.48{ }^{\circ} \mathrm{C}\right)$ and relative humidity $(74.49 \%)$ were recorded in the second planting season with a range of minimum-maximum temperature and relative humidity of between 25.02 ${ }^{\circ} \mathrm{C}$ and $35.95{ }^{\circ} \mathrm{C}$ and $59.38 \%$ to $89.60 \%$. In overall, climatic conditions throughout the experimental period in both planting seasons were almost similar. Therefore, confounding factors due to differences in temperature and relative humidity between the year 2017 and 2018 throughout the experimental period were negligible and insignificant.

\section{THE DYNAMICS OF SOIL WATER POTENTIAL AND LEAF RELATIVE WATER CONTENT}

The level of soil water potential and LRWC were gradually decreases starting from day 2 RS was initiated 
a)

YEAR 2017

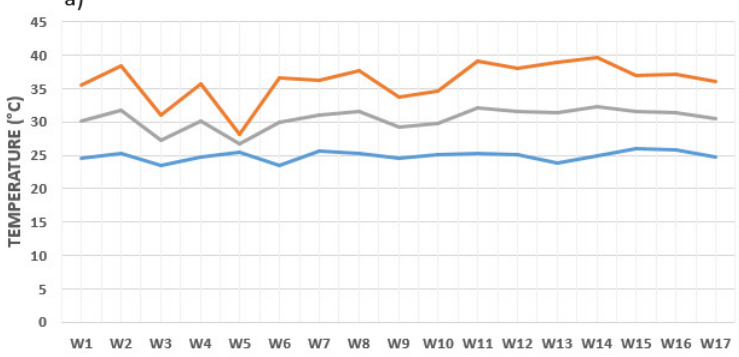

b)

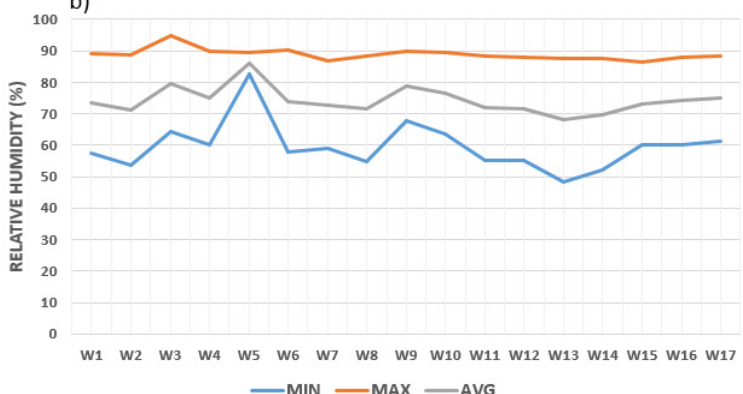

YEAR 2018
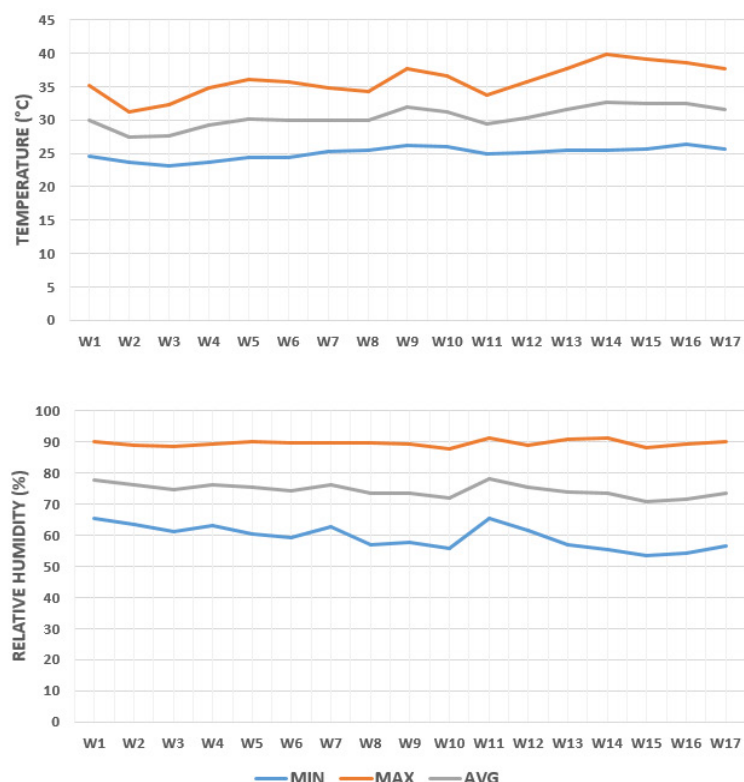

FIGURE 1 . The temperature and relative humidity throughout experiment. The maximum, minimum and average value of a) temperature $\left({ }^{\circ} \mathrm{C}\right)$; and b) relative humidity (\%) throughout the experiment (W1 - W17). W: number of weeks

(Figure 2). The LRWC dropped to about $40 \%$ on day 6 after RS started when soil water potential recorded at below $-60 \mathrm{kPa}$. All RS plants were then re-watered and soil water potential was restored to normal level $(0$

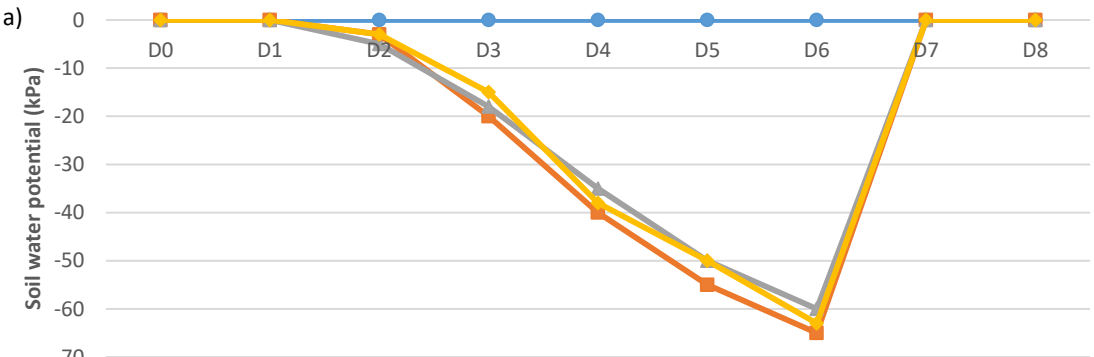

b)

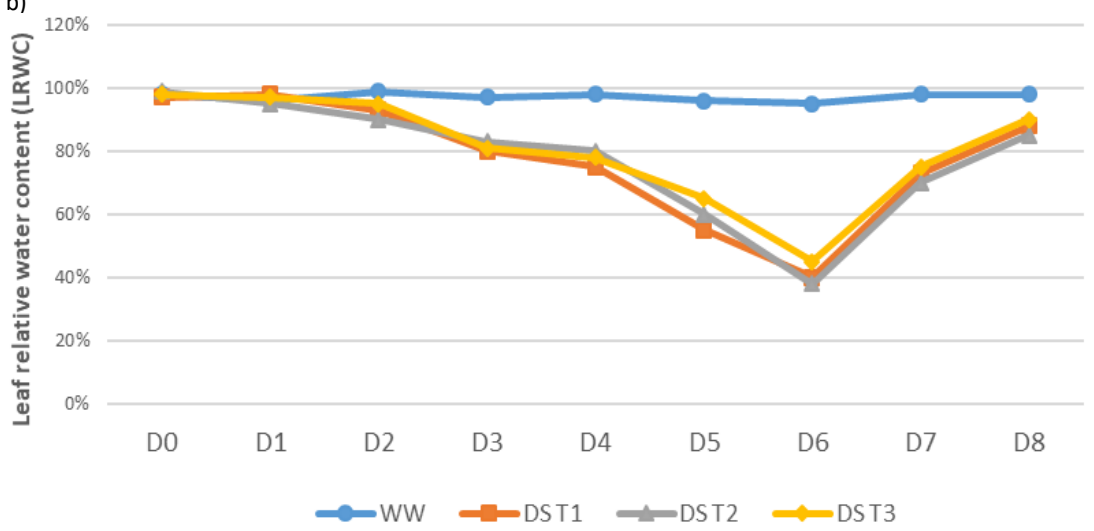

FIGURE 2. The soil water potential and leaf relative water content during reproductive stage drought stress treatment. WW: Well-watered; RS T1: Drought stressed T1 (nonprimed control); RS T2: Drought stressed T2 (hydro-priming); and RS T3: Drought stressed T3 (osmo-priming). The D0, D1, D2, D3, D4, D5, D6, D7 and D8 indicated number of days during reproductive stage drought stress treatment 
$\mathrm{kPa}$ ) on the next day. In contrast, the LRWC was gradually restored to normal level at above $80 \%$ on day 2 after rewatering (day 8 of RS imposition).

\section{SEEDLING GROWTH PERFORMANCE OF PRIMED SEEDS}

The T3 recorded significantly higher seedling growth attributes as compared to T2 and T1 in IR64 (i.e. RL and CGR) and MR297 (i.e. SL, RL, TL, and CGR) for the first planting season (Table 1). For the second planting season, T3 was not significantly different with T2 and T1 in IR64 but significantly higher in SL and CGR in MR297.

\section{AGRONOMIC PERFORMANCE OF PRIMED SEEDS}

Overall, seed priming mainly T2 and T3 were ineffective in improving yield components attributes of rice under both conditions of WW and RS (Table 2). The SN for drought stressed IR64 in the first season was recorded at 268 seeds (T1), 265 seeds (T2) and 281 seeds (T3). The second season also recorded non-significantly different values at 283 seeds (T1), 311 seeds (T2) and 291 seeds (T3). A similar trend of non-significant difference in SN between seed priming treatments was recorded in the drought stressed MR297 in both seasons (42 seeds in T1, 62 seeds in T2 and 82 seeds in T3 for the first season, and 31 seeds in T1, 71 seeds in T2 and 58 seeds in T3 for the second season).

Concurrently, the GY of drought stressed IR64 was statistically similar at $6.11 \mathrm{~g}$ (T1), $5.59 \mathrm{~g}$ (T2), and $6.75 \mathrm{~g}$ (T3) for the first season, and $6.64 \mathrm{~g}$ (T1), $6.88 \mathrm{~g}$ (T2) and $6.99 \mathrm{~g}$ (T3) for the second season. The drought stressed MR297 also recorded no significant difference in the GY between seed priming treatments mainly $0.85 \mathrm{~g} \mathrm{(T1),}$ $1.47 \mathrm{~g}$ (T2) and $1.92 \mathrm{~g} \mathrm{(T3)}$ for the first season, and 0.63 $\mathrm{g}$ (T1), $1.73 \mathrm{~g}$ (T2) and $1.27 \mathrm{~g}$ (T3) for the second season. There was also a non-significant difference between seed priming treatment in the HI for both varieties in both planting seasons. These results indicated that seed priming treatments in the present study were ineffective in improving agronomic performance of primed seeds under reproductive stage drought. There was also no significant difference in the SN, GY, and HI between seed priming treatments under the WW for both IR64 and MR297 in both planting seasons.

TABLE 1. Mean comparison analysis of seedling growth performance

\begin{tabular}{|c|c|c|c|c|c|c|}
\hline Treatment & $\mathrm{SL}(\mathrm{cm})$ & $\mathrm{RL}(\mathrm{cm})$ & $\mathrm{TL}(\mathrm{cm})$ & $\mathrm{LAI}\left(\mathrm{cm}^{2}\right)$ & $\operatorname{CGR}\left(\mathrm{g}^{-1}\right.$ day $\left.^{-1}\right)$ & NAR $\left(\mathrm{g} \mathrm{cm}^{-2}\right.$ day $\left.^{-1}\right)$ \\
\hline & Season 1 & & & & & \\
\hline & \multicolumn{6}{|c|}{ IR64 } \\
\hline $\mathrm{T} 1$ & $17.67^{\mathrm{b}}( \pm 0.64)$ & $9.35^{\mathrm{ab}}( \pm 0.53)$ & $27.02^{\mathrm{b}}( \pm 1.12)$ & $2.86^{\mathrm{a}}( \pm 0.25)$ & $\left.0.009^{c} \pm 0.0015\right)$ & $0.006^{\mathrm{a}}( \pm 0.0009)$ \\
\hline $\mathrm{T} 2$ & $20.68^{\mathrm{a}}( \pm 0.51)$ & $8.43^{\mathrm{b}}( \pm 0.25)$ & $29.12^{\mathrm{ab}}( \pm 0.55)$ & $3.24^{\mathrm{a}}( \pm 0.21)$ & $0.018^{\mathrm{b}}( \pm 0.00089)$ & $0.007^{\mathrm{a}}( \pm 0.0003)$ \\
\hline \multirow[t]{2}{*}{$\mathrm{T} 3$} & $21.10^{\mathrm{a}}( \pm 0.65)$ & $10.67^{\mathrm{a}}( \pm 0.59)$ & $31.77^{\mathrm{a}}( \pm 1.09)$ & $3.21^{\mathrm{a}}( \pm 0.35)$ & $0.024^{\mathrm{a}}( \pm 0.0018)$ & $0.007^{\mathrm{a}}( \pm 0.0003)$ \\
\hline & \multicolumn{6}{|c|}{ MR297 } \\
\hline $\mathrm{T} 1$ & $18.25^{\mathrm{b}}( \pm 0.62)$ & $8.60^{\mathrm{b}}( \pm 0.28)$ & $26.85^{\mathrm{b}}( \pm 0.80)$ & $2.41^{\mathrm{b}}( \pm 0.12)$ & $0.005^{\mathrm{c}}( \pm 0.001)$ & $0.003^{\mathrm{b}}( \pm 0.0005)$ \\
\hline $\mathrm{T} 2$ & $18.83^{b}( \pm 0.70)$ & $9.52^{\mathrm{b}}( \pm 0.44)$ & $28.35^{\mathrm{b}}( \pm 1.03)$ & $2.78^{\mathrm{ab}}( \pm 0.16)$ & $0.014^{\mathrm{b}}( \pm 0.001)$ & $0.007^{\mathrm{a}}( \pm 0.0009)$ \\
\hline \multirow[t]{3}{*}{$\mathrm{T} 3$} & $21.05^{\mathrm{a}}( \pm 0.39)$ & $12.93^{\mathrm{a}}( \pm 0.59)$ & $33.98^{\mathrm{a}}( \pm 0.80)$ & $2.98^{\mathrm{a}}( \pm 0.13)$ & $0.023^{\mathrm{a}}( \pm 0.003)$ & $0.007^{\mathrm{a}}( \pm 0.0008)$ \\
\hline & Season 2 & & & & & \\
\hline & \multicolumn{6}{|c|}{ IR64 } \\
\hline $\mathrm{T} 1$ & $18.13^{\mathrm{a}}( \pm 1.12)$ & $11.40^{\mathrm{a}}( \pm 0.88)$ & $29.53^{\mathrm{a}}( \pm 1.50)$ & $2.82^{\mathrm{a}}( \pm 0.30)$ & $0.008^{\mathrm{a}}( \pm 0.002)$ & $0.004^{\mathrm{a}}( \pm 0.001)$ \\
\hline $\mathrm{T} 2$ & $20.73^{\mathrm{a}}( \pm 0.43)$ & $9.00^{\mathrm{a}}( \pm 0.29)$ & $29.73^{\mathrm{a}}( \pm 0.39)$ & $3.19^{\mathrm{a}}( \pm 0.23)$ & $0.013^{\mathrm{a}}( \pm 0.002)$ & $0.005^{\mathrm{a}}( \pm 0.001)$ \\
\hline \multirow[t]{2}{*}{$\mathrm{T} 3$} & $20.45^{\mathrm{a}}( \pm 0.53)$ & $10.83^{\mathrm{a}}( \pm 0.64)$ & $31.28^{\mathrm{a}}( \pm 0.72)$ & $3.16^{\mathrm{a}}( \pm 0.32)$ & $0.013^{\mathrm{a}}( \pm 0.005)$ & $0.004^{\mathrm{a}}( \pm 0.001)$ \\
\hline & \multicolumn{6}{|c|}{ MR297 } \\
\hline $\mathrm{T} 1$ & $17.95^{\mathrm{a}}( \pm 1.02)$ & $7.88^{\mathrm{b}}( \pm 0.76)$ & $25.83^{\mathrm{b}}( \pm 1.57)$ & $2.57^{\mathrm{a}}( \pm 0.30)$ & $0.004^{\mathrm{b}}( \pm 0.001)$ & $0.002^{\mathrm{a}}( \pm 0.0003)$ \\
\hline $\mathrm{T} 2$ & $18.08^{\mathrm{a}}( \pm 1.08)$ & $8.98^{\mathrm{b}}( \pm 0.51)$ & $27.07^{\mathrm{ab}}( \pm 1.28)$ & $2.69^{\mathrm{a}}( \pm 0.18)$ & $0.007^{\mathrm{b}}( \pm 0.002)$ & $0.003^{\mathrm{a}}( \pm 0.0009)$ \\
\hline $\mathrm{T} 3$ & $19.25^{\mathrm{a}}( \pm 0.71)$ & $11.55^{\mathrm{a}}( \pm 0.80)$ & $30.80^{\mathrm{a}}( \pm 0.84)$ & $2.81^{\mathrm{a}}( \pm 0.12)$ & $0.017^{\mathrm{a}}( \pm 0.004)$ & $0.005^{\mathrm{a}}( \pm 0.00089)$ \\
\hline
\end{tabular}

Means with the same letter at every column did not significantly different by Tukey's test $(\alpha=0.05)$. SL $=$ Shoot length, $R L=R o o t$ length, TL $=$ Total seedling length, $\mathrm{LAI}$ $=$ Leaf area index, $\mathrm{CGR}=$ Crop growth rate, $\mathrm{NAR}=$ Net assimilation rate 
TABLE 2. Mean comparison analysis of the agronomic performance

\begin{tabular}{|c|c|c|c|c|c|c|}
\hline \multirow{2}{*}{ Treatment } & \multicolumn{3}{|c|}{ IR64 } & \multicolumn{3}{|c|}{ MR297 } \\
\hline & SN & GY $(\mathrm{g})$ & HI & SN & GY $(g)$ & $\mathrm{HI}$ \\
\hline & \multicolumn{6}{|l|}{ Season 1} \\
\hline & \multicolumn{6}{|c|}{ Well-watered (WW) } \\
\hline $\mathrm{T} 1$ & $598.33^{\mathrm{a}}( \pm 40.72)$ & $13.19^{\mathrm{a}}( \pm 0.87)$ & $0.57^{\mathrm{a}}( \pm 0.03)$ & $445.00^{\mathrm{a}}( \pm 55.16)$ & $11.52^{\mathrm{a}}( \pm 1.42)$ & $0.46^{\mathrm{a}}( \pm 0.003)$ \\
\hline $\mathrm{T} 2$ & $560.67^{\mathrm{a}}( \pm 61.56)$ & $15.76^{\mathrm{a}}( \pm 2.14)$ & $0.60^{\mathrm{a}}( \pm 0.03)$ & $410.67^{\mathrm{a}}( \pm 31.43)$ & $10.32^{\mathrm{a}}( \pm 0.98)$ & $0.44^{\mathrm{a}}( \pm 0.05)$ \\
\hline \multirow[t]{2}{*}{$\mathrm{T} 3$} & $522.33^{\mathrm{a}}( \pm 48.36)$ & $14.91^{\mathrm{a}}( \pm 1.05)$ & $0.59^{\mathrm{a}}( \pm 0.01)$ & $500.33^{\mathrm{a}}( \pm 12.73)$ & $12.11^{\mathrm{a}}( \pm 0.08)$ & $0.42^{\mathrm{a}}( \pm 0.01)$ \\
\hline & \multicolumn{6}{|c|}{ Reproductive stage drought stress (RS) } \\
\hline $\mathrm{T} 1$ & $268.00^{\mathrm{a}}( \pm 27.21)$ & $6.11^{\mathrm{a}}( \pm 0.45)$ & $0.36^{\mathrm{a}}( \pm 0.03)$ & $42.33^{\mathrm{a}}( \pm 13.62)$ & $0.85^{\mathrm{a}}( \pm 0.27)$ & $0.08^{\mathrm{a}}( \pm 0.03)$ \\
\hline $\mathrm{T} 2$ & $264.67^{\mathrm{a}}( \pm 12.13)$ & $5.59^{\mathrm{a}}( \pm 0.43)$ & $0.32^{\mathrm{a}}( \pm 0.05)$ & $62.00^{\mathrm{a}}( \pm 25.70)$ & $1.47^{\mathrm{a}}( \pm 0.65)$ & $0.14^{\mathrm{a}}( \pm 0.05)$ \\
\hline T3 & $280.67^{\mathrm{a}}( \pm 15.24)$ & $6.75^{\mathrm{a}}( \pm 0.56)$ & $0.35^{\mathrm{a}}( \pm 0.06)$ & $81.67^{\mathrm{a}}( \pm 22.00)$ & $1.92^{\mathrm{a}}( \pm 0.59)$ & $0.16^{\mathrm{a}}( \pm 0.06)$ \\
\hline
\end{tabular}

Season 2

\begin{tabular}{lcccccc}
\multicolumn{7}{c}{ Well-watered $(W W)$} \\
T1 & $591.67^{\mathrm{a}}( \pm 26.62)$ & $14.59^{\mathrm{a}}( \pm 0.62)$ & $0.61^{\mathrm{a}}( \pm 0.02)$ & $441.33^{\mathrm{a}}( \pm 49.46)$ & $11.51^{\mathrm{a}}( \pm 1.17)$ & $0.47^{\mathrm{a}}( \pm 0.001)$ \\
$\mathrm{T} 2$ & $553.00^{\mathrm{a}}( \pm 18.52)$ & $13.58^{\mathrm{a}}( \pm 0.45)$ & $0.55^{\mathrm{a}}( \pm 0.08)$ & $435.67^{\mathrm{a}}( \pm 48.42)$ & $11.14^{\mathrm{a}}( \pm 1.27)$ & $0.46^{\mathrm{a}}( \pm 0.003)$ \\
$\mathrm{T} 3$ & $524.00^{\mathrm{a}}( \pm 134.25)$ & $12.97^{\mathrm{a}}( \pm 3.40)$ & $0.59^{\mathrm{a}}( \pm 0.02)$ & $478.33^{\mathrm{a}}( \pm 64.13)$ & $11.84^{\mathrm{a}}( \pm 1.65)$ & $0.45^{\mathrm{a}}( \pm 0.007)$
\end{tabular}

Reproductive stage drought stress (RS)

\begin{tabular}{ccccccc} 
T1 & $283.33^{\mathrm{a}}( \pm 36.03)$ & $6.64^{\mathrm{a}}( \pm 0.96)$ & $0.37^{\mathrm{a}}( \pm 0.04)$ & $30.67^{\mathrm{a}}( \pm 20.33)$ & $0.63^{\mathrm{a}}( \pm 0.38)$ & $0.05^{\mathrm{a}}( \pm 0.03)$ \\
$\mathrm{T} 2$ & $311.33^{\mathrm{a}}( \pm 26.59)$ & $6.88^{\mathrm{a}}( \pm 0.71)$ & $0.37^{\mathrm{a}}( \pm 0.03)$ & $70.67^{\mathrm{a}}( \pm 33.65)$ & $1.73^{\mathrm{a}}( \pm 0.90)$ & $0.13^{\mathrm{a}}( \pm 0.05)$ \\
$\mathrm{T} 3$ & $291.33^{\mathrm{a}}( \pm 51.13)$ & $6.99^{\mathrm{a}}( \pm 1.47)$ & $0.34^{\mathrm{a}}( \pm 0.09)$ & $58.00^{\mathrm{a}}( \pm 36.02)$ & $1.27^{\mathrm{a}}( \pm 0.86)$ & $0.08^{\mathrm{a}}( \pm 0.06)$ \\
\hline
\end{tabular}

Means with the same letter at every column did not significantly different by Tukey's test $(\alpha=0.05)$. SN $=$ Number of seeds, GY $=$ Grain yield, and HI $=$ Harvest index

\section{CORRELATION ANALYSIS}

The correlation analysis (Table 3) indicated that GY was significantly and positively correlated with CGR, NAR, SN, and HI but was not significantly correlated with other growth performance attributes such as SL, RL, TL, and LAI. This indicated that early seedling growth attributes such as SL, RL, TL, and LAI do not significantly affect GY. Briefly, result of the present study indicated that although seed priming treatment significantly improves early seedling growth of rice, the advantages of vigorous seedling growth was not significantly correlated with the yield components attributes as shown in Table 3.

\section{DISCUSSION}

The significant effects of RS on growth and yield performance of rice have been reported in many studies (Ikmal et al. 2019; Salleh et al. 2020; Shamsudin et al. 2016a; 2016b; Swamy et al. 2017). The primed seeds particularly T2 and T3 recorded significantly higher seedling growth attributes as compared to T1. Increment in the SL, RL, TL, and LAI has resulted on higher NAR, and CGR of the primed seeds. These results were in agreement with Kalhori et al. (2018) which reported that seed priming treatments enhanced seed germination and seedling growth of rice. Harris et al. (2001) also reported that seed priming treatments 
led to faster emergence, better growth and stand establishment, early flowering, increased seed tolerance to the adverse environment and higher yield in various crops such as wheat, rice, maize and soybean.

TABLE 3. Correlation analysis of seedling growth and yield components attributes

\begin{tabular}{|c|c|c|c|c|c|c|c|c|c|}
\hline SL & RL & $\mathrm{TL}$ & LAI & CGR & NAR & SN & GY & $\mathrm{HI}$ & \\
\hline \multirow[t]{9}{*}{1} & $0.292^{* *}$ & $0.819^{* *}$ & $0.712^{* *}$ & $0.345^{* *}$ & $0.098^{\mathrm{ns}}$ & $0.060^{\mathrm{ns}}$ & $0.056^{\mathrm{ns}}$ & $0.044^{\mathrm{ns}}$ & SL \\
\hline & 1 & $0.788^{* *}$ & $0.177^{\mathrm{ns}}$ & $0.292^{* *}$ & $0.153^{\mathrm{ns}}$ & $0.010^{\mathrm{ns}}$ & $-0.015^{\mathrm{ns}}$ & $0.027^{\mathrm{ns}}$ & $\mathrm{RL}$ \\
\hline & & 1 & $0.565^{* *}$ & $0.398^{* *}$ & $0.155^{\mathrm{ns}}$ & $0.045^{\text {ns }}$ & $0.027^{\mathrm{ns}}$ & $0.044^{\mathrm{ns}}$ & $\mathrm{TL}$ \\
\hline & & & 1 & $0.192^{\mathrm{ns}}$ & $-0.003^{\mathrm{ns}}$ & $0.115^{\text {ns }}$ & $0.102^{\mathrm{ns}}$ & $0.092^{\mathrm{ns}}$ & LAI \\
\hline & & & & 1 & $0.814^{* *}$ & $0.404^{* *}$ & $0.394^{* *}$ & $0.306^{* *}$ & CGR \\
\hline & & & & & 1 & $0.354^{* *}$ & $0.355^{* *}$ & $0.297^{* *}$ & NAR \\
\hline & & & & & & 1 & $0.991^{* *}$ & $0.904^{* *}$ & $\mathrm{SN}$ \\
\hline & & & & & & & 1 & $0.908^{* *}$ & GY \\
\hline & & & & & & & & 1 & HI \\
\hline
\end{tabular}

** and * denotes significant correlation at $\mathrm{p} \leq 0.01$ and $\mathrm{p} \leq 0.05$ and 'ns' denotes not significantly correlated at $\mathrm{p} \leq 0.05$. SL $=\mathrm{Shoot}$ length, RL $=\mathrm{Root}$ length, TL $=$ Total seedling length, $\mathrm{LAI}=$ Leaf area index, $\mathrm{CGR}=\mathrm{Crop}$ growth rate, $\mathrm{NAR}=$ Net assimilation rate, $\mathrm{SN}=$ Number of seeds, $\mathrm{GY}=\mathrm{Grain}$ yield, and $\mathrm{HI}=\mathrm{Harvest}$ index

Musa et al. (1999) also recorded a comparable outcome with significantly faster seedlings emergence, better stand establishment and about $47 \%$ increment of GY in the primed seeds as compared to non-primed seeds. Classically, significant effects of seed priming in improving seedling growth and stand establishment had been observed and reported by Heydecker (1973). Previous study by Harris et al. (1999) explained that primed seeds had faster emergence and better seedling growth due to advancement in the metabolic activity of the seeds. Results from laboratory experiment by Salleh et al. (2020) also indicated that primed-seeds had higher $\alpha$-amylase activity resulted in faster conversion of starch to soluble sugar leading to higher germination rate and seedling growth performance. Hence, Singh et al. (2015) suggested that seed priming could be a cost-effective technology to enhance rapid and uniform emergence that will lead to better stand establishment and higher harvestable crop yield.

Nonetheless, results obtained indicated that there was no significant difference among seed priming treatments (i.e. T1, T2, and T3) in the yield components attributes mainly the SN, GY, and $\mathrm{HI}$ in both varieties IR64 and MR297 under WW and RS in both planting seasons. These results, however, were incongruent with previous studies by Binang et al. (2012) and Harris et al. (2007) which reported significant improvement in the seed germination, growth performance and harvestable GY of primed seeds under field condition. This might be due to other confounding factors such as types of crop, types of priming media and concentration, priming duration, the temperature during priming and the seeds storage condition that interfered the performance of primed seeds (Singh et al. 2015).

For instance, the higher agronomic performance of primed seeds reported by Harris et al. (2007) was on maize using zinc sulphate solution as a priming medium. Binang et al. (2012) on the other hand used New Rice for Africa (NERICA) rice cultivar in their study as opposed to the present study which used rice cultivar for South-east Asia region mainly IR64 and MR297. Chen and Arora (2011) stated that improvement in the germination performance and seedling growth of primed seeds may also be a species, variety and seed lot-specific which resulted in the inconsistency outcome. All these interrelated factors may contribute to insignificant effects of seed priming on yield components under WW and RS observed in the present study.

In addition, Lutts et al. (2016) stated that improvement in primed seeds would normally obvious during germination and early seedling growth but progressively disappears at the adult stage. A similar finding was also reported by Chen and Arora (2011) that there was no significant difference between 
primed and non-primed seeds in the stress tolerance ability and antioxidant activities of the five-week-old's spinach seedlings under RS. Therefore, they concluded that osmopriming-mediated promotive effect on stress tolerance, however, may diminish during the seedling growth (Chen \& Arora 2011).

Above all, the results of the present study indicated that positive effects of seed priming were only significant during the germination stage and early seedling growth. In brief, the drought stress memory of primed seeds had been proven to be effective on improving germination performance of rice under RS (Salleh et al. 2020) but the stress tolerance advantage was found to be temporary and could not be prolonged to the reproductive growth stages as shown by the result in the present study. Although there is a possibility of experimenting under field condition may produce a different outcome, other confounding factors might be interfered such as pest and disease attack and other forms of climate-related stress such as flooding, intermittent drought, and heat stress.

Nevertheless, although primed seeds may recruit the drought stress memory during priming and re-drying process in seed priming treatment, the acquired drought stress memory was temporary and only significant during germination process under drought condition. The acquired drought stress memory, however, could not be lasted until the reproductive growth stages.

\section{CONCLUSION}

In conclusion, yield components were significantly lower in RS plant as compared to WW control. Results of the present study also indicated that agronomic performance of primed seeds mainly $\mathrm{T} 2$ and $\mathrm{T} 3$ were not significantly difference with non-primed control (T1) both under WW and RS conditions. Seed priming was ineffective in improving the agronomic performance of rice under RS. Therefore, another sustainable approach particularly breeding for RS tolerant rice should be emphasized in alleviating drought stress challenges in rice cultivation.

\section{ACKNOWLEDGEMENTS}

This study was supported by the Toray Science Foundation, Japan through Malaysia Toray Science Foundation (MTSF) under Science and Technology Research Grant STRG18/G302; and Universiti Kebangsaan Malaysia (UKM) under Research University Grant DCP-2017-004/2. We acknowledged assistance from Dr. Mohd Shukri Mat Ali@ Ibrahim and Puan Site Noorzuraini Abd Rahman from MARDI Genebank and Seed Centre for providing rice seeds.

\section{REFERENCES}

Basra, S.M.A., Farooq, M., Tabassam, R. \& Ahmad, N. 2005. Physiological and biochemical aspects of pre-sowing seed treatments in fine rice (Oryza sativa L.). Seed Science and Technology 33(3): 623-628.

Binang, W.B., Shiyam, J.O. \& Ntia, J.D. 2012. Effect of seed priming method on agronomic performance and cost effectiveness of rainfed, dry-seeded NERICA rice. Research Journal of Seed Science 5(4): 136-143.

Chen, K. \& Arora, R. 2013. Priming memory invokes seed stress-tolerance. Environmental and Experimental Botany 94: 33-45.

Chen, K. \& Arora, R. 2011. Dynamics of the antioxidant system during seed osmopriming, post-priming germination, and seedling establishment in spinach (Spinacia oleracea). Plant Science 180: 212-220.

Farooq, M., Usman, M., Nadeem, F., Rehman, H.U., Wahid, A., Basra, S.M.A. \& Siddique, K.H.M. 2019. Seed priming in field crops: Potential benefits, adoption and challenges. Crop and Pasture Science 70(9): 731-771.

Farooq, M., Basra, S.M.A., Tabassum, R. \& Afzal, I. 2006. Enhancing the performance of direct seeded fine rice by seed priming. Plant Production Science 9(4): 446-456.

Harris, D., Rashid, A., Miraj, G., Arif, M. \& Shah, H. 2007. 'On-farm' seed priming with zinc sulphate solution-A cost-effective way to increase the maize yields of resourcepoor farmers. Field Crops Research 102(2): 119-127.

Harris, D., Raghuwanshi, B.S., Gangwar, J.S., Singh, S.C., Joshi, K.D., Rashid, A. \& Hollington, P.A. 2001. Participatory evaluation by farmers of on-farm seed priming in wheat in India, Nepal and Pakistan. Experimental Agriculture 37(3): 403-415.

Harris, D., Joshi, A., Khan, P.A., Gothkar, P. \& Sodhi, P.S. 1999. On-farm seed priming in semi-arid agriculture: Development and evaluation in maize, rice and chickpea in India using participatory methods. Experimental Agriculture 35(1): 15-29.

Heydecker, W. 1973. Accelerated germination by osmotic seed treatment. Nature 246: 42-44.

Hunt, R. 1990. Basic Growth Analysis. London: Unwin Hayman Ltd.

Ikmal, M.A., Nurasyikin, Z., Tuan Nur Aqlili Riana, T.A., Puteri Dinie Ellina, Z., Wickneswari, R. \& Noraziyah, A.A.S. 2019. Drought yield QTL ( $q D T Y$ ) with consistent effects on morphological and agronomical traits of two populations of new rice (Oryza sativa L.) lines. Plants 8(6): 186.

Ikmal, M.A., Nurasyikin, Z., Arvind, K. \& Noraziyah, A.A.S. 2018. Evaluation of morpho-physiological traits of MRQ74 pyramided lines with drought yield QTLs. Euphytica 214: 98.

ISTA. 2016. International Rules for Seed Testing. Bassersdorf, Switzerland: International Seed Testing Association. 
Jisha, K.C., Vijayakumari, K. \& Puthur, J.T. 2013. Seed priming for abiotic stress tolerance: An overview. Acta Physiologiae Plantarum 35(5): 1381-1396.

Kalhori, N., Nulit, R., Azizi, P., Abiri, R. \& Atabki, N. 2018. Hydro priming stimulates seedling growth and establishment of Malaysian indica rice (MR219) under drought stress. Acta Scientific Agriculture 2(11): 9-16.

Lee, S.S. \& Kim, J. H. 1999. Morphological change, sugar content and $\alpha$-amylase activity of rice seeds under various priming conditions. Korean Journal of Crop Science 44(2): 138-142.

Lutts, S., Benincasa, P., Wojtyla, L., Kubala, S., Pace, R., Lechowska, K., Quinat, M. \& Garnczarska, M. 2016. Seed priming: New comprehensive approaches for an old empirical technique. In New Challenges in Seed Biology Basic and Translational Research Driving Seed Technology. DOI: $10.5772 / 64420$.

Mahajan, G., Sarlach, R.S., Japinder, S. \& Gill, M.S. 2011. Seed priming effects on germination, growth and yield of dry direct-seeded rice. Journal of Crop Improvement 25(4): 409-417.

Mouradi, M., Bouizgaren, A., Farissi, M., Makoudi, B., Kabbadj, A., Very, A.A., Sentenac, H., Qaddoury, A. \& Ghoulam, C. 2016. Osmopriming improves seeds germination, growth, antioxidant responses and membrane stability during early stage of Moroccan alfalfa populations under water deficit. Chilean Journal of Agricultural Research 76(3): 265-272.

Musa, A.M., Johansen, C., Kumar, J. \& Harris, D. 1999. Response of chickpea to seed priming in the High Barind Tract of Bangladesh. Inter Chickpea and Pigeonpea Newsletter 6: 20-22.

Salehzade, H., Shishvan, M.I., Ghiyasi, M., Forouzin, F. \& Siyahjani, A.A. 2009. Effect of seed priming on germination and seedling growth of wheat (Triticum aestivum L.). Research Journal of Biological Sciences 4: 629-631.

Salleh, M.S., Nordin, M.S. \& Puteh, A.B. 2020. Primed rice (Oryza sativa L.) seeds: Germination performance and biochemical changes under drought stress. Seed Science and Technology 48(3): 333-343.

Salleh, M.S., Nordin, M.S., Ghaffar, M.B.A., Shahari, R., Zainuddin, Z. \& Puteh, A. 2018. Effects of pre-anthesis drought stress on yield components and seed quality of rice (Oryza sativa L.). Malaysian Applied Biology 47(5): 149-155.

Schonfeld, M.A., Johnson, R.C., Carver, B.F. \& Mornhinweg, D.W. 1988. Water relations in winter wheat as drought resistance indicator. Crop Science 28: 526-531.

Shamsudin, N.A.A., Swamy, B.P.M., Ratnam, W., Cruz, M.T.S., Sandhu, N., Raman, A.K. \& Kumar, A. 2016a. Pyramiding of drought yield QTLs into a high quality Malaysian rice cultivar MRQ74 improves yield under reproductive stage drought. Rice 9(1): 21.
Shamsudin, N.A.A., Swamy, B.P.M., Wickneswari, R., Sta. Cruz, M.T., Anitha, R. \& Kumar, A. 2016b. Marker assisted pyramiding of drought yield QTLs into popular Malaysian rice cultivar, MR219. BMC Genetics 2016: 17-30.

Singh, H., Jassal, R.K., Kang, J.S., Sandhu, S.S., Kang, H. \& Grewal, K. 2015. Seed priming techniques in field crops - A review. Agricultural Reviews 36(4): 251-264.

Subedi, K.D. \& Ma, B.L. 2005. Seed priming does not improve corn yield in a humid temperate environment. Agronomy Journal 97: 211-218.

Swamy, B.P.M., Shamsudin, N.A.A., Rahman, S.N.A., Mauleon, R., Ratnam, W., Sta. Cruz, M.T. \& Kumar, A. 2017. Association mapping of yield and yield-related traits under reproductive stage drought stress in rice (Oryza sativa L.). Rice 10(1): 21.

Watson, D.J. 1947. Comparative physiological studies on the growth of field crops: I. Variation in net assimilation rate and leaf area between species and varieties and between years. Annals of Botany 11: 41-76.

Mohd Syahmi Salleh, Mohd Shukor Nordin, Rozilawati Shahari \& Zarina Zainuddin

Department of Plant Science

Kulliyyah of Science

International Islamic University Malaysia

25200 Kuantan, Pahang Darul Makmur

Malaysia

Adam B. Puteh

Department of Crop Science

Faculty of Agriculture

Universiti Putra Malaysia

43400 UPM Serdang, Selangor Darul Ehsan

Malaysia

Mohamad Bahagia Ab-Ghaffar

Industrial Crop Research Centre

Malaysian Agricultural Research and Development Institute

13200 Kepala Batas, Pulau Pinang

Malaysia

Noraziyah Abd Aziz Shamsudin*

Department of Biological Sciences and Biotechnology

Faculty of Science and Technology

Universiti Kebangsaan Malaysia

43600 UKM Bangi, Selangor Darul Ehsan

Malaysia

*Corresponding author; email: nora_aziz@ukm.edu.my

Received: 6 October 2020

Accepted: 25 February 2021 